\title{
Seismic Stratigraphy of Pleistocene Deltaic Deposits in Bahía Blanca Estuary, Argentina
}

\author{
SALVADOR ALIOTTA ${ }^{1,2}$, SILVIA S. GINSBERG ${ }^{1,3}$, DARÍO GIAGANTE ${ }^{1}$, \\ LAURA G. VECCHI ${ }^{2,3}$ and MARTA M. SALVATIERRA ${ }^{1,2}$ \\ ${ }^{1}$ Instituto Argentino de Oceanografía, CONICET, La Carrindanga Km 7, 8000 Bahía Blanca, Argentina \\ ${ }^{2}$ Departamento de Geología, UNS, San Juan 672, 8000 Bahía Blanca, Argentina \\ ${ }^{3}$ Departamento de Ingeniería Civil, UTN, FRBB, 11 de Abril 461, 8000 Bahía Blanca, Argentina \\ Manuscript received on June 12, 2013; accepted for publication on October 14, 2013
}

\begin{abstract}
The Bahía Blanca estuary (Argentina) has a morphological configuration resulting from hydrological and sedimentary processes related to Late Quaternary sea level changes. This estuarine system occupies a large coastal plain with a dense net of tidal channels, low-altitude islands and large intertidal flats. Little is known about the sedimentary units of the marine subbottom. Therefore, a stratigraphical analysis of the northern coast of Bahía Blanca estuary was carried out using high resolution seismic $(3.5 \mathrm{kHz})$ in order to: i) define Quaternary sequences, ii) describe sedimentary structures, and iii) determine the paleoenvironmental conditions of sedimentation. The seismic stratigraphic data collected and their correlation with drilling lithological data show five seismic sequences (S1, S2, S3, S4 and S5), of which S1-S2 were found to be associated with a continental paleoenvironment of Miocene-Pleistocene age. Sequences S3 and S4, whose lithology and seismic facies (paleochannel structures and prograding reflection configurations), were defined on these materials, to evidence the development of an ancient deltaic environment which was part of a large Pleistocene drainage system. The S5 sequence was formed during the Holocene transgressiveregressive process and complete the seismostratigraphic column defined in the present study.
\end{abstract}

Key words: Bahía Blanca estuary, deltaic sequences, marine seismic, Pleistocene, stratigraphy.

\section{INTRODUCTION}

The variations observed in the coastal paleoenvironments formed during the Late Quaternary are closely related to sea level changes. In line with this, both the ancient geographical, geomorphological and sedimentological conditions and coastal marine dynamics prove to be the main variables in determining different coastal environmental systems. The analysis of the stratigraphic characteristics of sedimentary units and their lateral and vertical

Correspondence to: Salvador Aliotta

E-mail: gmaliott@criba.edu.ar facies at the subbottom are also useful tools to identify the geological evolutionary processes as well as the sedimentary paleoenvironments that are related to Late Quaternary sea level changes. On the other hand, seismostratigraphic data are invaluable sources of evidence, particularly at the time of determining the evolutionary processes that occurred in different environments, such as bays, estuaries, fiords and deltas (Duncan et al. 2000, Fleischer et al. 2001, Hiscott 2001, Quaresma et al. 2001, GarciaGil et al. 2002, Karisiddaiah et al. 2002, Lobo et al. 2003, Mallinson et al. 2005, Nordfjord et al. 2005, 
Artusi and García de Figueiredo 2007, Dalrymple and Choi 2007, Liquete et al. 2008, among others). Nevertheless, coastal and marine studies that have been carried out to date taking into account the seismostratigraphic characteristics of the Southwest Atlantic region (Brazil, Uruguay and Argentina) are scarce (Parker and Paterlini 1990, Aliotta et al. 1999, 2009, Quaresma et al. 2001, Bujalesky et al. 2004, Corrêa et al. 2005, Weschenfelder et al. 2006, 2008, Giagante et al. 2011, among others). Furthermore, although petroleum activities have in fact greatly contributed to the knowledge about sedimentary basins, little is known about the upper stratigraphic levels where the characteristics of the different coastal evolutionary stages during geological history are recorded.

In view of the above, and based on the limited set of geological-stratigraphical data known on the sedimentary cover of the Argentine coast, the purpose of the present study was to carry out a seismostratigraphic analysis of the subbottom in a sector of Bahía Blanca estuary, in an attempt to identify its seismic configuration as well as the paleoenvironmental conditions of sedimentation that prevailed during Late Quaternary coastal evolution.

Bahía Blanca estuary is located in a large coastal area of Buenos Aires province, Argentina (Fig. 1). Its most distinctive morphological feature is the presence of a network of tidal channels which are separated by islands and large tidal flats. Its channels are, in general, interconnected and form a mesotidal system. They are meander-type and have different dimensions and depths (Ginsberg and Perillo 1990, Ginsberg et al. 2009, Ginsberg and Aliotta 2011). Its coastal area is also characterized by the presence of large muddy tidal flats which were formed by the progradation of clayey silt sediments during the last postglacial regressive event (Aliotta and Farinati 1990, Aliotta et al. 2004), whose fossils in life position reveal radiocarbon ages ranging between 3000 and 1200 years B.P. (Farinati and Aliotta 1997, Aliotta et al. 2004).
The Principal Channel in the estuary is the main path to one of the largest ports in Argentina where important petrochemical activities are regularly carried out, thus imprinting both national and international economic relevance to this sector. Our study area covers a sector of the Principal Channel extending from Ingeniero White Harbor to Belgrano Harbor (Fig. 1). This sector is characterized by a maximal depth of $15 \mathrm{~m}$ and the presence of a large intertidal area (Globo Islands) as well as large tidal channels (Cabeza de Buey, La Lista and La Vieja).

\section{MATERIALS AND METHODS}

Seismo-acoustic prospection was carried out on board the ship "Buen Día Señor" which belongs to the Instituto Argentino de Oceanografía (IADO). During navigation, a base map containing navigation charts of the Argentine Naval Hydrographic Service and georeferenced aerial photographs, were used. Position data was controlled in real time using a differential globe positioning system (DGPS) connected to navigation software. A digital-analogical echo sounder (Bathy-500MF of $200 \mathrm{kHz}$ ) was used to define the bathymetric characteristics of the study area (Fig. 1). Transverse and longitudinal profiles were carried out at the Principal Channel and La Vieja Channel (Fig. 1) with a $100-150 \mathrm{~m}$ average spacing.

Seismic prospection of the marine subbottom was carried out simultaneously to bathymetric survey, using high resolution seismic profiling operating with a frequency of $3.5 \mathrm{kHz}$. The emission source used was a transmitter Geopulse 5430 A with a maximum power of $10 \mathrm{Kw}$, thus optimizing the seismic penetration and enabling the reach to measure several meters of depth at the subbottom. Data were collected and processed using specific software. Tidal correction of bathymetric data was also performed and depths were referenced to the Datum Plane of Ingeniero White Harbor. 


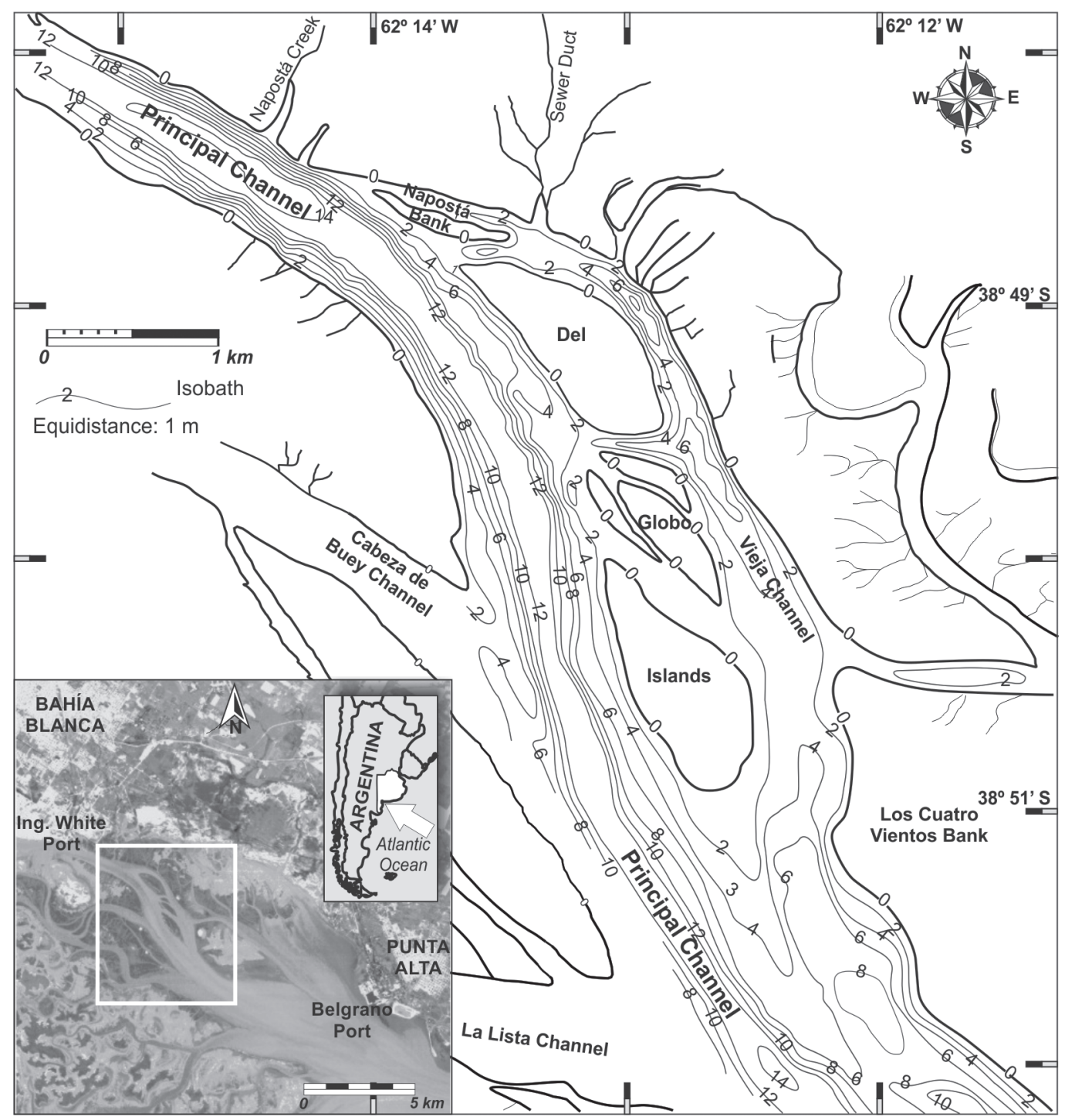

Fig. 1 - Study area. Bahía Blanca estuary.

Data processing and analysis of seismic records were carried out taking into account: i) the identification of discontinuity surfaces and sequence boundaries; ii) the types of seismic reflector termination (downlap, onlap, toplap, truncation); iii) the seismic facies and pattern within the sequences; and iv) the thickness and continuity of the sequences identified. Taking into account the sedimentary sequences recorded and the propagation velocities for different materials (D'Olier 1979, Reynolds 1997), the thickness of seismic facies was estimated for an average speed of $1650 \mathrm{~m} / \mathrm{s}$.

\section{RESULTS AND DISCUSSION}

Our seismic data analysis allowed us to identify five seismic stratigraphic sequences in the study area. Seabed morphology is in general associated with those units that either outcrop at or form part of the marine subbottom in certain areas of the estuary. The morphological characteristics of the area are representative of sequences at seabed and, in several cases, they imprint distinguishing traits on them. Thus, in order to be able to fully and accurately construct a seismostratigraphic column of the sequences identified including 
their lateral variations and regional continuity, they were described following the order of their stratigraphic position. The correlation of seismic profiles with borehole data (Nedeco-Arconsult 1983) showed the lithological characteristics of the subbottom.

Sequence S1 is the oldest seismic sequence identified in the study area. It partially outcrops in the Principal Channel and forms a large acoustic basement. It is formed of dark gray, highly compacted, fine-to-medium sand as well as of some silt layers.
Its internal structure is characterized by scarce and isolated seismic reflectors having no lateral continuity (Fig. 2). Based on its sedimentological characteristics (color, lithology and degree of compactation), its materials could be related to Arroyo Chasicó Formation (Late Miocene) which is highly extended towards the northeastern area of Bahía Blanca (Zárate et al. 2007) and which has been identified in different sectors of the subbottom of the estuary (Aliotta et al. 1992, Lizasoain and Aliotta 1995, Spagnuolo 2005).

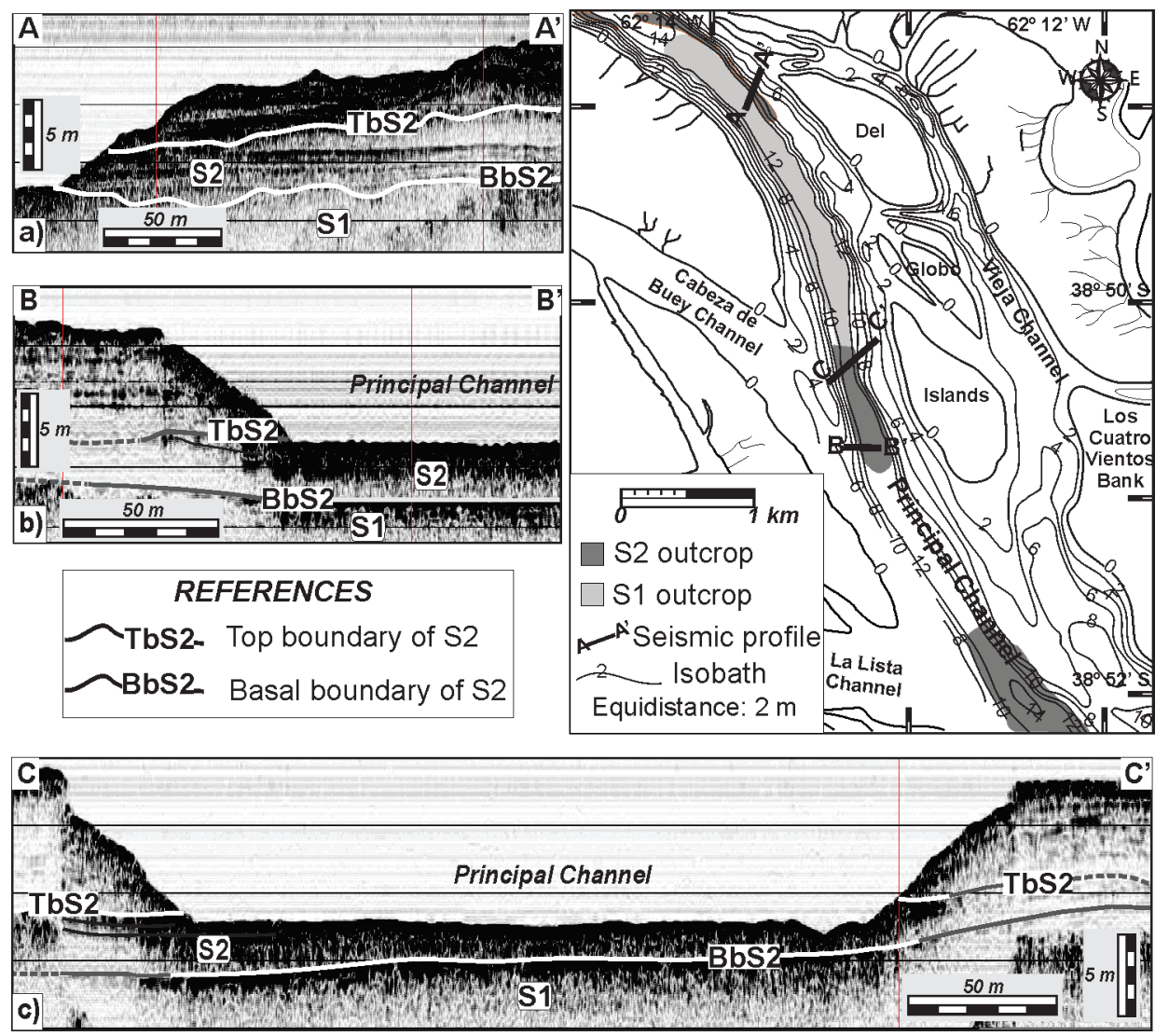

Fig. 2 - Seismic sequences S1 and S2. Areal distribution and seismic profiles.

The seismostratigraphic column identified in the study area follows upward with sequence S2, which shows a semitransparent seismic configuration, with horizontal reflectors with weak acoustic response and lateral continuity (Fig. 2). This sequence is formed by cemented silty clayey sand, ranging from dark gray to light brown. The seismic and sidescan sonar records collected showed that S2 outcrops at the bottom of the Principal Channel, forming escarpments on the lee side of the channel, with terrace-like structures of up to $7 \mathrm{~m}$. Previous studies carried out in the estuary (Aliotta et al. 1991, 1992, Aliotta and Lizasoain 1998, Spagnuolo 2005) also enabled the identification of sedimentary 
sequences with characteristics similar as those in S2, thus allowing its correlation with the Pampiano Formation (Fidalgo et al. 1975), a fluvial-eolian area (Plio-Pleistocene) largely distributed along Buenos Aires province. These deposits form the compacted substrate upon which, on the coastal sector of Bahía Blanca, sediments which had been mobilized during the Holocene transgressiveregressive process, were deposited (Aliotta and Farinati 1990, Aliotta et al. 1996).

On the other hand, the small channels facies identified in S2 confirm a genesis with fluvial intervention, in line with Plio-Pleistocene environments which left stratigraphic records in other sectors of the Argentine coast. Interestingly, Cavalloto et al. (2005) observed, on the coastal plain at the head of La Plata river, the presence of brown sandy clayey silt sediments with calcareous materials of continental origin which seemed to belong to "Puerto Olivos" depositional sequence, which is equivalent to the Pampiano Formation. On the other hand, based on their correlations of glaciations from the Patagonia (southern Argentina) with sequences from the Pampeana region, Rabassa et al. (2005) claimed that during the Late PliocenePleistocene continental areas were duplicated and sea level decreased up to $140 \mathrm{~m}$ during the Last Glacial Maximum. The pioneer work of Fray and Ewing (1963) in Argentine Shelf determined that during the Late Pleistocene (20-18 kyr) the sea-level position was $110-120 \mathrm{~m}$ below that of the present.

Seismic sequence S3 was identified on the slopes of the Principal Channel, reaching a maximal thickness of $5 \mathrm{~m}$. Its seismic structure is formed by reflectors with apparent inclination towards the east (Fig. 3) and with truncations as a result of erosion on the escarpments forming the channel flanks. Its thickness decreases towards the east until fully wedging (Fig. 3, C-C'y D-D'). Based on previous borehole data (Nedeco-Arconsult 1983), it can be observed that S3 is formed of fine, gray and moderately compacted sandy clay and that it is in contact with S2 through an acoustically well-defined discontinuity surface having a softly ondulated conformation. Taking into account the lithology of S3, the presence of fragments of hard compacted clay and cemented silt is indicative of the action of an erosive process which affected the lower substratum. The hardness of S2 eroded basement suggests the action of a medium-high energy agent, probably with preponderant fluvial action. In this respect, González Uriarte (1984) observed the presence of a paleorunoff pathway in Bahía Blanca estuary, which could have developed following an alignment characterized by the Chasicó-Salinas Chicas-Salitral de la Vidriera depression and the Principal Channel whose drainage brought sediments to the region within a deltaic environment.

On the other hand, taking into account Mitchum et al.'s (1977) classification, it can be observed that the seismic facies in S3 evidences a relationship between oblique-tangential prograding structures and shingled structures (Fig. 3). This seismostratigraphic pattern is associated to deposits derived from a relatively high-sediment contribution in an environment of slightly deep waters. This is indicative of the preponderant fluvial influence which favored the formation of an environment with high sediment deposition, as shown by the large areal development of this sequence.

The characteristic sedimentary structural pattern of S3 shows variations, such as the presence of sub-parallel reflectors having a very gentle slope and being located in the upper part of the sequence (Fig. 3, B-B'). Interestingly, Liquete et al. (2008) observed a similar pattern with sub-parallel facies located in the upper part of seismic sequences near the Llobregat River mouth (Spain). In agreement with the depositional environment proposed for S3, Liquete et al. (2008) associated this structure type with horizontal deltaic deposits. In line with this, in Bahía Blanca estuary Aliotta et al. (2004) identified a seismic facies with parallel-sub-parallel 


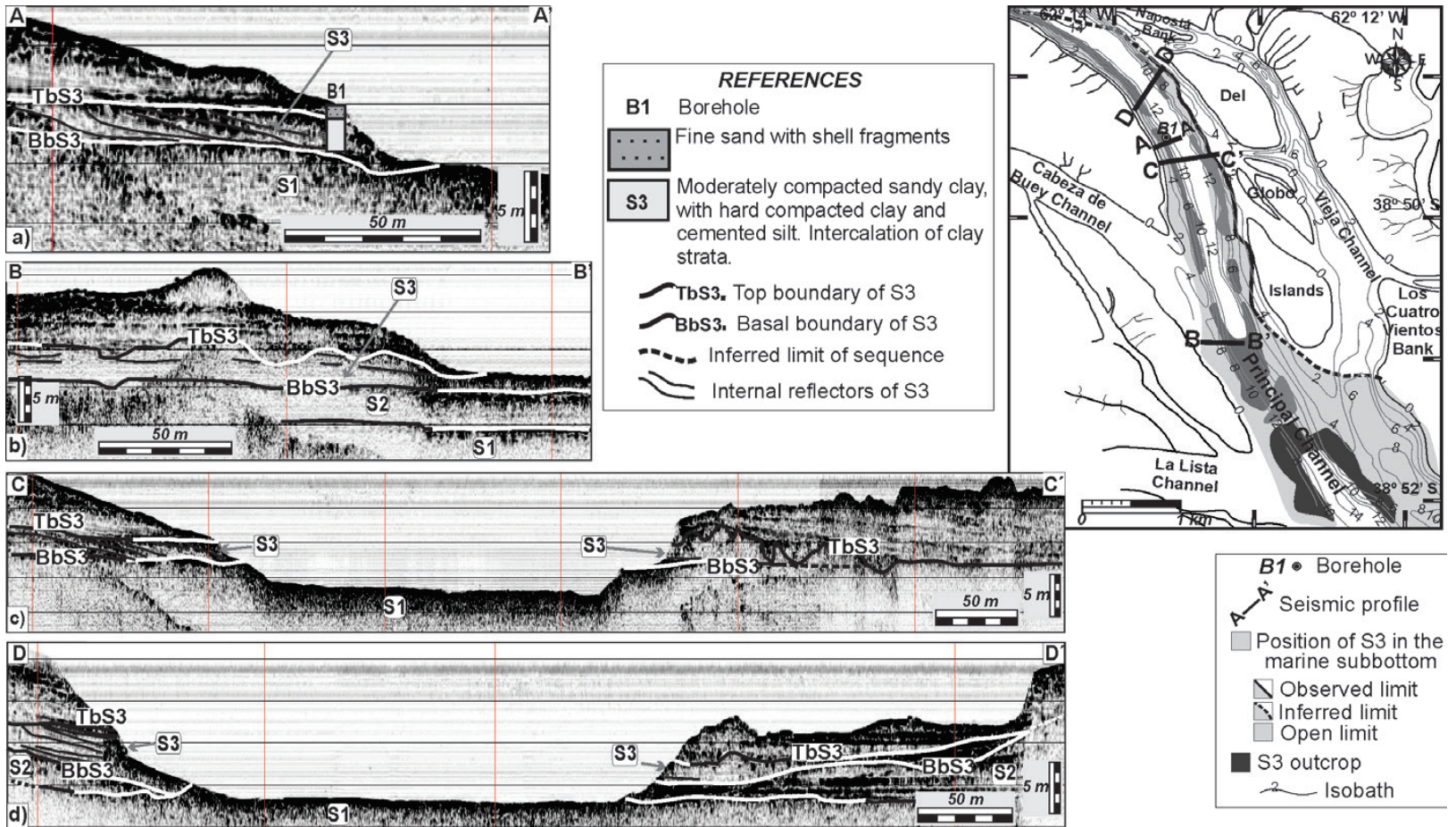

Fig. 3 - Seismic sequence S3. 3.5-kHz profiles showing stratigraphic features. Areal distribution of S3 in the marine subbottom and lithological data (borehole).

stratification and high lateral continuity which was further associated with alluvial flats formed during a Pleistocene fluvial-deltaic paleoenvironment. Paleochannel structures exhibiting v-shaped cuts can also be on the upper boundary of S3 as evidence of an ancient drainage system, which, together with the toplap termination of its internal reflectors, give support to the erosive discontinuity of the upper boundary of S3. The seismostratigraphic characteristics of S3 (toplap reflection termination, oblique progradational configuration) are related to a sedimentary paleoenvironment with laterally overlapping strata. In line with this, Gökaşan et al. (2005) identified seismic configurations similar to $\mathrm{S} 3$ in a sequence of deltaic lobe of lateral development. Together, both the seismic and lithological characteristics identified in S3 (gray, sandy clayey, moderately compacted) are indicative of a fluvial-deltaic sedimentary paleoenvironment. Concomitantly, Aliotta et al. (2004) identified these types of materials by acoustic facies with parallel-sub-parallel stratification (slight crossbedding and high lateral continuity), prograding reflector configurations and paleochannel filling materials, towards the west (inner part of the estuary). The sequence defined as S3 in the present study is correlated with the seismostratigraphic unit previously identified by Aliotta et al. (2004) and is also related to a large Pleistocene drainage system that formed part of the old drainage basin of Colorado River. In agreement with this, in the study on the continental coastal area in the south of Bahía Blanca, González Uriarte (1984) made reference to a paleodelta formed in the domain of the Colorado River drainage basin. Concomitantly, by means of satellite image analysis, Spalletti and Isla (2003) delimited deltaic paleolobes in the Colorado River and defined lobe 2 as that corresponding to the region of Bahía Blanca estuary, which was strongly degraded as a result of tidal action. In addition, at the subbottom of the marine platform adjacent to the coastal region of the estuary, Aliotta et al. 
(1999) observed clayey silt materials which are also related to the terminal sector of an ancient deltaic environment of Colorado River.

Furthermore, the distribution of S3 at the marine subbottom has allowed us to infer the east side boundary of the sedimentary lobe that formed the old delta (Fig. 3). Thus, towards the east of the Principal Channel, the boundary of the distal sector of the deltaic lobe was seismically evidenced towards the western flanks of the Globo Islands. In contrast, towards the west-southeast, S3 shows not only continuity but also an increase in its thickness.
As to the sedimentary unit identified as S4, it was found located over S3 which is separated from S4 by an erosive unconformity. The correlation with drilling data indicated that the seismic sequence S4 is moderately compacted and that it is characterized by the presence of intercalated fine sand strata and gray clayey sediments with no biogenic material (Fig. 4). The hardness of these materials is evident in the relictic structures belonging to $\mathrm{S} 4$, outcropping at the sea bottom (Fig. 4, B-B') and identified in the lateral sonar records (Fig. 4, C).

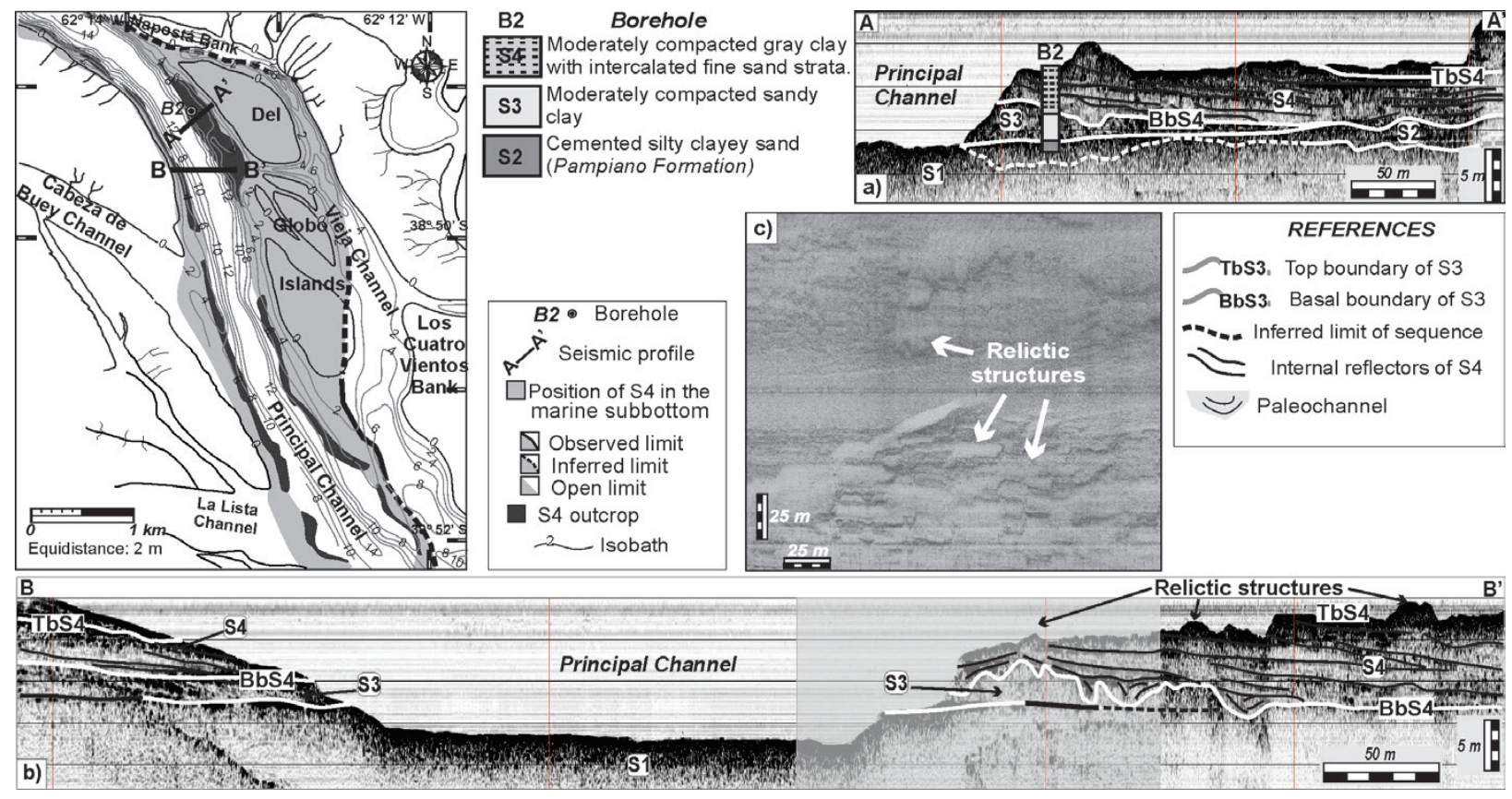

Fig. 4 - Seismic sequence S4. A-A` and B-B`: 3.5-kHz profiles showing stratigraphic features. C: side scan sonar record. Areal distribution of S4 in the marine subbottom and lithological data (borehole).

Furthermore, paleochannel structures were identified in the lower section of S4. These configurations have been found at the subbottom, both towards the east and the west of the Principal Channel. The sedimentary filling of paleochannels show facies varying from prograding to divergent and complex (Fig. 4). These seismic facies are, in general, related with thick-grain sedimentation and relatively high energy (Riggs et al. 1992, Nordfjord et al. 2005, Mallinson et al. 2005). It could thus be concluded that the filling material of the incisions corresponds to sandy sediments.

The geometric-stratigraphic analysis of the channel filling structures (symmetric, asymmetric, chaotic) reveals the sedimentary and evolutionary process of the channel (Gibling 2006). Thus, based on the seismic arrangement of reflectors, a lateral accretion domain can be inferred in those paleochannels whose sedimentary structures display a complex pattern. On the other hand, the seismic 
reflectors showing relative symmetry among each other, indicate that a vertical aggradation could have been dominant. It can also be observed that both symmetric and asymmetric filling structures are combined in several of the paleochannels identified (Fig. 5). The data collected from the integral analysis of these paleochannels also indicate that during the process of sedimentary deposition, the transversal section of the ancient streambeds became gradually smaller and evolved until colmatation. Figure 5 shows the areal distribution of the paleochannels found in the basement of S4. After having identified these ancient fluvial structures, a 3D scheme was carried out in a sector of the eastern flank of the Principal Channel, enabling the reconstruction of the paleodrainage pattern. A northeast-southeast orientation could thus be identified for the streambeds, enabling the association of these runoff pathways with the continental area located northeast in our study area. These paleochannels are likely to be associated with the regional runoff pathway that formed part of the Colorado River paleodelta. Their configuration also help us associate them with ancient tributaries of a drainage system having characteristics similar to a deltaic environment. This association seems to be corroborated by the comparison of the dimensions of the paleochannels present in sequence S4 with those observed by Gibling (2006). The latter attributed a thickness ranging between $1 \mathrm{~m}$ and $35 \mathrm{~m}$ and a width indicating from $10 \mathrm{~m}$ to 300 $\mathrm{m}$ to the water courses of delta tributaries. The ancient channels identified in sequence $\mathrm{S} 4$ are approximately $10-50 \mathrm{~m}$ wide and the streambed depth ranges between 2 and $4 \mathrm{~m}$.

The eastern boundary of sequence S4 seems to go further than the eastern flank of La Vieja Channel (Fig. 4), the high reflectivity of the discontinuity surface which behaves as the floor of sequence S4, led us to conclude that prior to the deposition of sequence S4 a period could have elapsed during which the top of sequence S3 behaved as a platform exposed to erosion. The paleochannel filling seismic facies identified on the base of this sequence do, in fact, show evidence of this geological process. Towards the upper part, the lateral growth of the sequence could have occurred with relative continuity as shown by the inclined stratification towards the east. This upper facies therefore seems to respond to an environment related to deposits coming from the distal part of a marginal mudflat within the deltaic environment. This could, in turn, be the consequence of a lateral migration of the fluvial-deltaic system in response to a displacement towards the south of the old drainage network. One of the factors involved in this migration process could have been a sea-level rise. In this respect, in a regional study conducted by Spalletti and Isla (2003) it was suggested that changes occurred at the base level of the old deltaic system of the Colorado River as a result of an oscillation relative to the sea level.

The seismostratigraphic characteristics of sequences S3 and S4 hereinbefore described, as well as the type of materials found, are both indicative of a fluvial-deltaic deposition paleoenvironment that was formed during the Late Pleistocene-Early Holocene. The seismic configurations associated to this paleoenvironment have also been found in other inner and outer areas of the estuary (Aliotta et al. 1991,1999, 2004), thus showing its vast regional extension.

On the other hand, the analysis of the sedimentary structures of sequences S3 and S4 and their correlation with evolutionary models of deltaic systems (Fisk 1961), allowed us to elaborate the representative schematic profile of the study area (Fig. 6). In sequence S3 it could be observed that reflectors have a major inclination when they are located closer to the center of the deltaic lobe or of the principal drainage system while they either tend to be horizontal and/or copy the preexisting topography as they get closer to the 

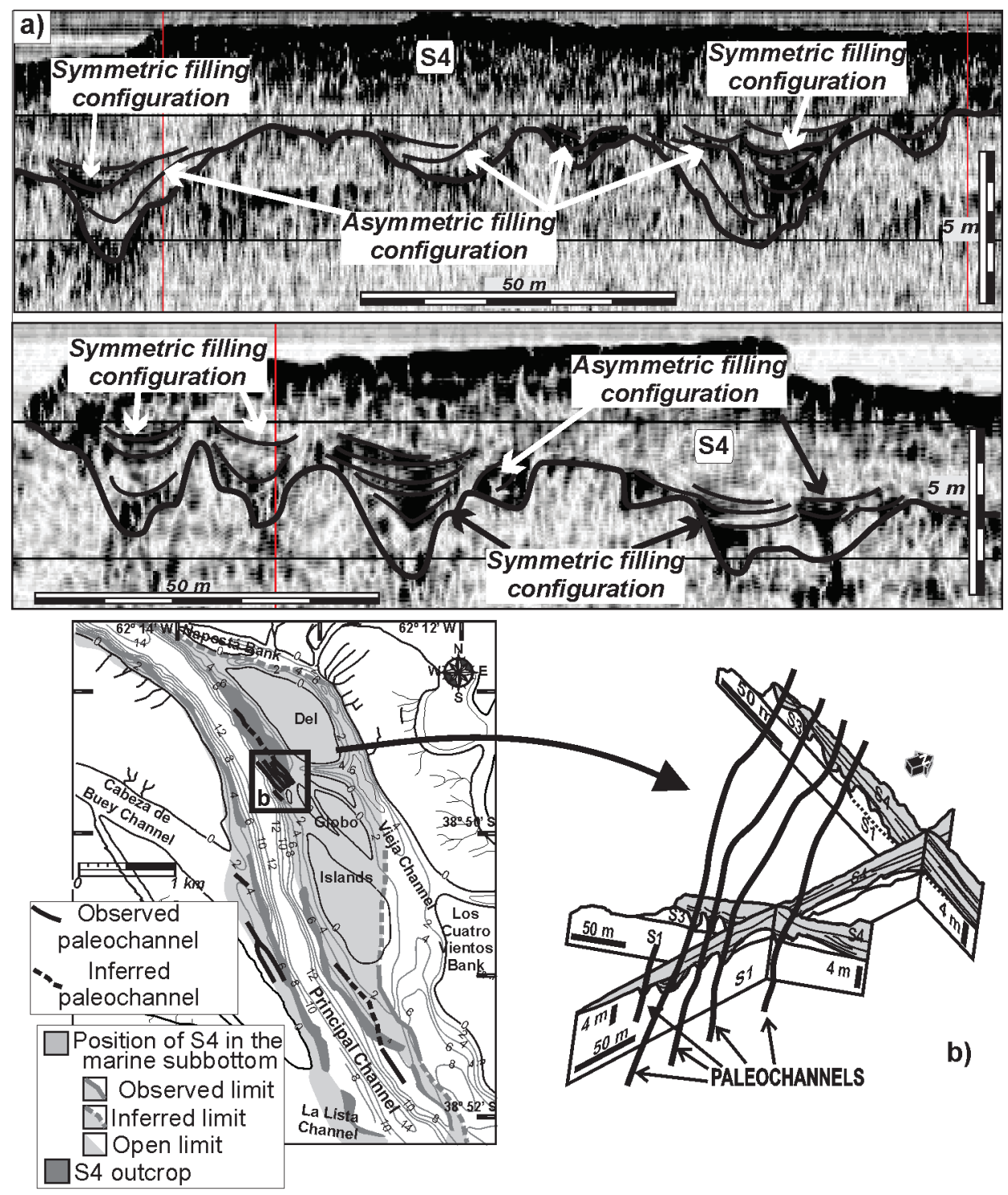

Fig. 5 - Paleochannels in the basal boundary of S4. 3.5-kHz sub-bottom records with both symmetric and asymmetric filling structures. Areal distribution of the paleochannels and 3D scheme of a sector of the eastern flank of the Principal channel.

most distal sector. This sequence was affected by a subsequent erosive action as evidenced in the toplap terminations on the top of the sequence. Such geological process evidenced by the small channel incisions located on the floor of sequence $\mathrm{S} 4$ is associated to reactivation pulses of the fluvial tributaries from a deltaic environment.

The prolongation of sequences S3 and S4 towards the east, which is related to the prolongation of deltaic lobes, is limited mainly by the basal surface which shows a decrease in the depth of the top of the sequence underlying the deltaic sediments (sequences S1 or S2). In addition, the changes observed under hydric conditions and sediment supply, could also be associated to these topographic restrictions. These changes could, in turn, be associated to the relative sea-level rise and to subsequent changes at the level of the base of the fluvial system. On the other hand, the presence of toplap terminations in the reflectors of sequence 
S4 is interpreted as being indicative of the erosive action of waves and tidal currents which affected the old deltaic coastal plain during the postglacial transgression process.

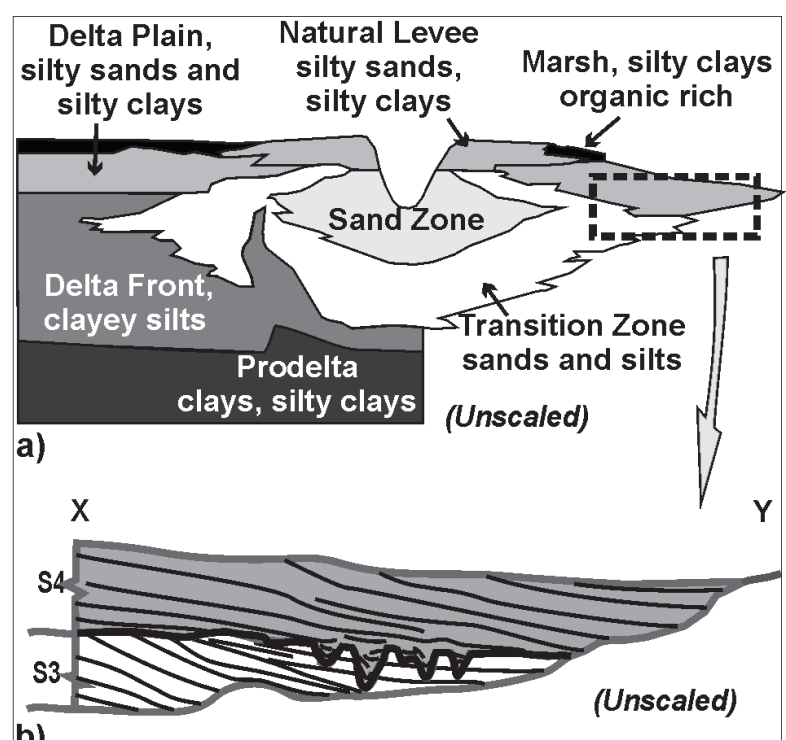

b)

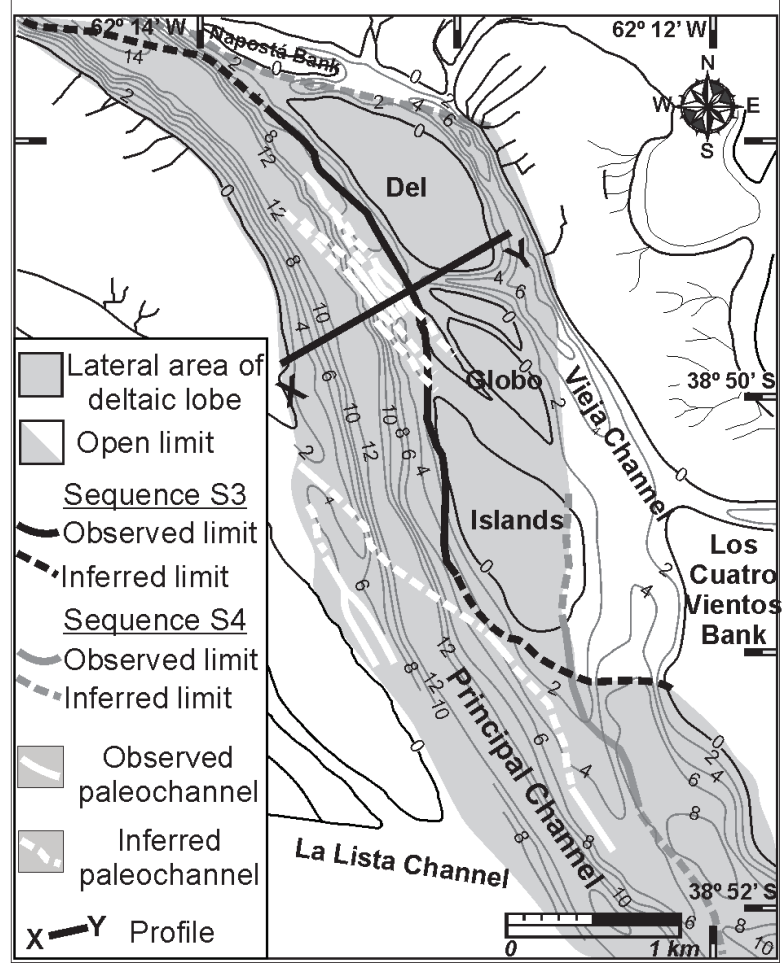

Fig. 6 - Correlation of the sedimentary structures of sequences S3 and S4 with a model of deltaic system. a) Deltaic sequences (Fisk 1961); b) representative schematic profile of the study area. Subbottom distribution and limits of S3 and S4.
The seismic stratigraphic column analyzed in the present study continues upwards with sequence S5 whose floor is represented by a notable surface of erosive discontinuity (S4 top). The latter becomes evident in certain sectors of the subbottom in the area of La Vieja Channel, where the floor of sequence S5 forms the basal erosive surface with v-shaped incisions and paleochannels facies. In the upper part of the slopes of the Principal Channel, sequence S5 is represented by sediments with sub-horizontal stratification whose reflectors are truncated as a result of erosion at the sea bottom. These strata which outcrop at the seabed are identified in the records of the lateral sonar thanks to their outstanding stratification.

The correlation of seismic data with data derived from drillings carried out in the eastern flank of the Principal Channel reveals that sequence S5 shows grain-decreasing towards the upper part. In its lower sector it is formed of gray, moderately dense, medium-to-coarse sand, which changes to gray silty clay, soft to medium dense, with shell in different proportions. Likewise, in some sectors the sediments representing the upper part of sequence S5 are displayed in layers evidencing a stratification towards the deepest channel areas. This seismostratigraphic configuration indicates the distribution and deposition of the sedimentary material intervening in the Holocene marine transgressive-regressive process. The latter is manifested in the coastal region emerging adjacent to the estuary by sand ridge accumulation with a high content of shell (Farinati and Aliotta 1987, 1997, Aliotta and Farinati 1990).

\section{CONCLUSION}

The representative seismostratigraphic column of our study area was constructed taking into account the lithological data collected and the data derived from the integral analysis of the seismic sequences identified at the subbottom of Bahía Blanca estuary. The deltaic sequences analyzed were located 
stratigraphically (Fig. 7). Light-brown, highly compacted, silty clay and sandy silt sediments all form a large regional acoustic-stratigraphic basement. These materials which correspond to a fluvial-continental sedimentary paleoenvironment correlate with Arroyo Chasicó Formation and Pampiano Formation, whose geological age extends from the late Miocene to the Pleistocene.

The constructed seismostratigraphic column shows variations in the paleoenvironmental conditions occurring between the Late Pleistocene and the Early Holocene, which were considerably influenced by a large fluvial drainage network developed in the southwestern area of Buenos Aires province. Thus, the sequences identified as S3 and S4 are indicative of the development of a fluvial-deltaic environment. Deposition of clayey sand layers with inclined-bedding sedimentation structures is predominant in sequence $\mathrm{S} 3$, oblique prograding, divergent and shingled configurations being the most outstanding seismic facies. In contrast, sequence S4 evidences a period of reactivation and redistribution of the drainage system during which paleochannel structures with different seismic configurations formed in its floor. The general and distinctive feature of this seismic sequence is its stratification which is marked by inclined reflectors towards the east-southeast. Both the seismostratigraphy and lithology of sequences S3 and S4 confirm their association with old deposits of deltaic lobes which formed part of a large Pleistocene drainage system.
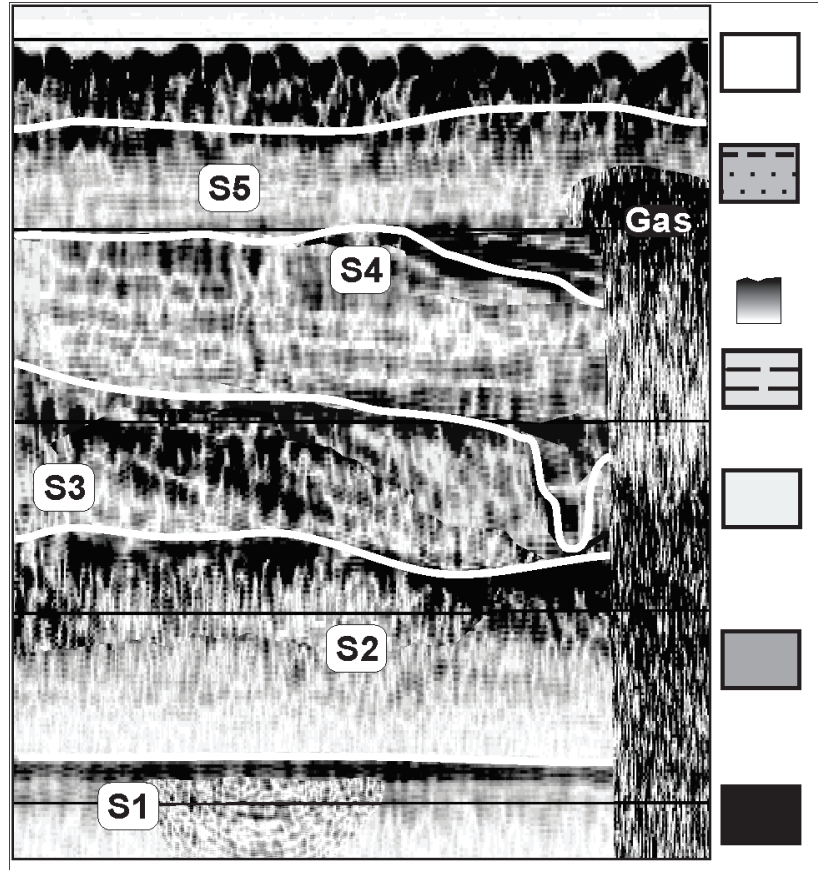

Modern sediments with sand, silt, clay and gravel in variable proportions. Shell fragments.

Upper Facies: Silty clay with shells. Lower Facies: Medium-tocourse sand.

Gas

Gray, soft compacted clay, with fine sand strata.

Gray, moderately compacted clayey sand, with hard clay pieces and cemented silt. Intercalation of clay layers

Light brown, cemented sandy clayey silt with compacted clay strata (Pampiano Formation).

Light brown, hard silty clay, (Arroyo Chasicó Formation?).

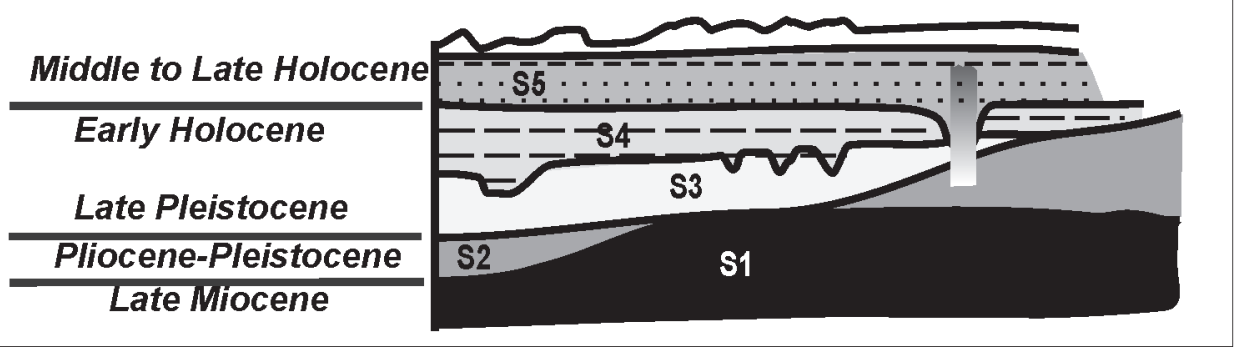

Fig. 7 - Deltaic sequences stratigraphy (S3 and S4). Seismic and lithological characterization. 
Towards middle-Holocene, sea-level rise began to affect Bahía Blanca coastal region. Medium-sand with variable proportions of biogenic remains cover, in general, the deltaic deposits whereas soft-to-moderately compacted silty clay sediments predominate in the shallower sectors. These materials form the seismic sequence S5. The advance of marine sediments as well as the rework and redistribution of fluvial-estuarine sediments facilitated the filling of ephemeral paleochannels with the subsequent modification of the coastal drainage network. Finally, the establishment of a large estuarine-marine environment in Bahía Blanca coastal region contributed to the development of numerous tidal channels separated by emerged sectors which currently form banks and islands.

\section{ACKNOWLEDGMENTS}

This research was supported by the following projects: PGI 24/H099 and 24/H107 (Secretaría de Ciencia y Técnica, UNS); PIP N 5538 and $\mathrm{N}^{\circ}$ 00699 (CONICET); PID 25/B028 (UTN, FRBB) and PICT 7-31666 (Agencia, MINCYT). We would like to thank three anonymous reviewers for their corrections and comments.

\section{RESUMO}

O estuário da Bahía Blanca (Argentina) tem uma configuração morfológica resultante de processos hidrológicos e sedimentares relacionados a mudanças do nível do mar durante o Quaternário Tardio. Este sistema estuarino ocupa uma ampla planície costeira com uma densa rede de canais de marés, ilhas de baixa altitude e extensas áreas de intermarés com baixa declividade. Nesta área, pouco se conhece sobre as unidades sedimentares do fundo marinho. Portanto, análise estratigráfica da costa norte do estuário da Bahía Blanca foi realizada usando sísmica de alta resolução (3,5 kHz) com a finalidade de: i) definir sequências quaternárias, ii) descrever estruturas sedimentares, e iii) determinar as condições paleoambientais de sedimentação. Os dados estratigráficos sísmicos obtidos e suas correlações litológicas com dados de perfuração apresentaram cinco sequências sísmicas (S1, S2, S3, S4 e S5), das quais S1-S2 foram correlacionadas com um paleoambiente continental referente ao MiocenoPleistoceno. Sequências S3 e S4, de fácies litológicas e sísmicas (estruturas de paleocanais e configurações de reflexão progradantes) foram definidas nestas sequências, evidenciando o desenvolvimento de um ambiente ancestral deltaico que foi parte de um amplo sistema de drenagem do Pleistoceno. A sequência S5 foi formada durante os processos transgressivo-regressivos do Holoceno e preenche a coluna sismo-estratigráfica definida neste estudo.

Palavras-chave: estuário da Bahía Blanca, sequências deltaicas, sísmica marinha, Pleistoceno, estratigrafia.

\section{REFERENCES}

AliotTA S AND FARINATI E. 1990. Stratigraphy of Holocene sand-shell ridges in the Bahía Blanca Estuary, Argentina. Mar Geol 94: 353-360.

ALIOTTA S AND LIZASOAIN GO. 1998. Facies sísmicas someras $(3,5 \mathrm{kHz})$ en el sector interno del estuario de Bahía Blanca, Argentina. X Congreso Latinoamericano de Geología, Buenos Aires, Actas II: 55-60.

AliotTa S, LIZASOAIN GO AND GINSBERG SS. 2004. Dinámica sedimentaria y evolución morfológica de un profundo canal del estuario de Bahía Blanca. AGA Rev 59(1): 14-28.

ALIOTTA S, LiZASOAIN GO AND LIZASOAIN W. 1991. Sedimentología y paleoambientes cuaternarios en el sector interno del estuario de Bahía Blanca, Argentina. An Inst Cienc del Mar y Limnol Univ Nal Autón México 18(1): 99-107.

Aliotta S, LizAsoAin GO AND LizAsoAin W. 1992. Sedimentos subsuperficiales entre Puerto Galván e Ing. White, canal principal del estuario de Bahía Blanca, Argentina. III Jornadas Geológicas Bonaerenses, La Plata, Actas, p. 213-217.

AliotTa S, LIZASOAIN GO, LIZASOAIN W AND GINSBERG SS 1996. Late Quaternary Sedimentary Sequence in the Bahía Blanca Estuary, Argentina. J Coastal Res 12(4): 875-882.

Aliotta S, Spagnulolo JO And FARINATI E. 2009. Origen de una roca de playa en la región costera de Bahía Blanca, Argentina. Pesq Geoc 36(1): 107-116.

Aliotta S, Spagnuolo JO, Ginsberg SS and Gelós EM. 1999. Sedimentos de fondo-subfondo y aspectos geomorfológicos de la plataforma continental entre el estuario de Bahía Blanca y bahía Anegada, provincia de Buenos Aires. AAS Revista 6(1-2): 19-35.

ARTUSI L AND GARCÍA DE FIgUEIREDO A. 2007. Sismoestratigrafía rasa da plataforma continental de Cabo FrioAraruama-RJ. Reva Bras Geofís 25(1): 7-16. 
Bujalesky G, Aliotta S And Isla F. 2004. Facies del subfondo del Canal Beagle, Tierra del Fuego. AGA Rev 59(1): 29-37.

Cavallotto JL, Violante RA and Colombo F. 2005. Evolución y cambios ambientales de la llanura costera de la cabecera del río de la Plata. AGA Rev 60(2): 353-367.

CORRÊA ICS, ALIOTTA S AND WeSCHENFELDER J. 2005. Estructura e Evolução dos Cordões Arenosos Pleistocênicos no Canal de Acesso à laguna dos Patos-RS, Brasil. Pesq Geoc 31(2): 69-78.

DALRYMPLE RW AND CHOI K. 2007. Morphologic and facies trends througth the fluvial-marine transition in tide-dominated depositional systems: A schematic framework for environmental and sequence-stratigraphic interpretation. Earth-Sci Rev 81: 135-174.

D'OLIER B. 1979. Side scan sonar and reflection seismic profiling. In: Dyer KR (Ed), Estuarine Hydrography and sedimentation. Cambridge University Pres, Cambridge, p. $57-86$.

DUNCAN CS, GOFF JA, AUSTIN JR JA AND FULTHORPE CS. 2000. Tracking the last sea-level cycle: seafloor morphology and shallow stratigraphy of the latest Quaternary New Jersey middle continental shelf. Mar Geol 170: 395-421.

FARINATI E AND ALIOTTA S. 1987. Malacofauna holocena de un paleodepósito litoral en las proximidades de Punta Alta, provincia de Buenos Aires, Argentina. Cuarto Congreso Latinoamericano de Paleontología, Bolivia, Actas, p. 574-585.

FARINATI E AND AliotTA S. 1997. Análisis de tafofacies transgresivas-regresivas holocenas, Estuario de Bahía Blanca, Argentina. AGA Rev 52(1): 56-64.

Fidalgo F, DE Francesco FO AND PAscual R. 1975. Geología superficial de la llanura bonaerense. Relatorio de Geología de la provincia de Buenos Aires. VI Congreso Geológico Argentino, Bahía Blanca, Actas, p. 103-138.

FISK HN. 1961. Bar-finger sands of the Mississippi delta. In: Geometry of Sandstone Bodies: American Association of Petroleum Geologists, $45^{\text {th }}$ Annual Meeting: Atlantic City, New Jersey, April 25-28, 1960, p. 29-52.

FLEISCHER P, ORSI TH, RICHARDSON MD AND ANDERSON AL. 2001. Distribution of free gas in marine sediments: a global overview. Geo-Mar Lett 21: 103-122.

FRAY C AND EWING M. 1963. Wisconsin sea level as indicated in Argentina continental shelf sediments. Philadelphia Acad Nat Sci Proc 115(6): 113-126.

GARCIA-GIL S, VILAS F AND GARCIA-GARCIA A. 2002. Shallow gas features in incised-valley fills (Ria de Vigo, NW Spain): a case study. Cont Shelf Res 22: 2303-2315.

Giagante D, Aliotta S, Ginsberg SS, Vecchi L AND SPAGNUOLO J. 2011. Evolution of a coastal alluvial deposit in response to the last Quaternary marine transgression, Bahía Blanca estuary, Argentina. Quaternary Res 75: 614-623.

GIBLING MR. 2006. Width and thickness of fluvial channel bodies and valley fills in the geological record: a literature compilation and classification. J Sediment Res 76: 731-770.
Ginsberg SS AND AliotTA S. 2011. Sediment Transport Circulation Pattern through Mesotidal Channels System. In: Ginsberg SS (Ed), Sediment Transport. InTech, Vienna, Austria 14: 275-294.

GinsBerg SS, ALIOTtA S AND LizASOAIN G. 2009. Morphodynamics and seismostratigraphy of a deep hole at tidal channel confluence. Geomorphology 104: 253-261.

Ginsberg SS AND Perillo GM. 1990. Channel Bank Recession in the Bahía Blanca estuary, Argentina. J Coastal Res 6(4): 999-1009.

Gökaşan E, Algan O, Hüseyin T, Meriç E, Türker A AND ŞINŞEK M. 2005. Delta formation at the southern entrance of Istanbul Strait (Marmara sea, Turkey): a new interpretation based on high-resolution seismic stratigraphy. Geo-Mar Lett 25: 370-377.

GonZÁLEZ URIARTE M. 1984. Características geomorfológicas de la porción continental que rodea la Bahía Blanca, provincia de Buenos Aires. IX Congreso Geológico Argentino, Actas III: 556-576.

HiscotT RN. 2001. Depositional sequences controlled by high rates of sediment supply, sea-level variations, and growth faulting: the Quaternary Baram Delta of northwersten Borneo. Mar Geol 175: 67-102.

KARISIDDAIAH SM, VEERAYYA M AND VORA KH. 2002. Seismic and sequence stratigraphy of the central western continental margin of India: late-Quaternary evolution. Mar Geol 192: 335-353.

Liquete C, CANALs M, De Mol B, De Batist Mand TRINCARdi F. 2008. Quaternary stratal architecture of the Barcelona prodeltaic continentel shelf (NW Mediterranean). Mar Geol 250: 234-250.

LizASOAIN GO AND AliotTA S. 1995. Fondo rocoso en el canal de navegación del estuario de Bahía Blanca, Argentina. $4^{\mathrm{o}}$ Jornadas Geológicas y Geofísicas Bonaerenses, Actas 1: 295-303.

Lobo FJ, Dias JMA, GONZÁlez R, HERnÁNDEZ-Molina FJ, Morales JA AND DíAs DEL Río V. 2003. High-resolution seismic stratigraphy of a narrow, bedrock-controlled estuary: the Guadiana estuarine system, SW Iberia. J Sediment Res 73(6): 973-986.

Mallinson D, Riggs S, Thieler ER, Culver S, Farrell K, Foster DS, Corbett DR, Horton B AND Wehmiller JF. 2005. Late Neogene and Quaternary evolution of the northern Albemarle Embayment (mid-Atlantic continental margin, USA). Mar Geol 217: 97-117.

Mitchum JR, VAIL RM AND SANGREe PR. 1977. Seismic Stratigraphy and Global Changes of Sea Level, Part 6: Stratigraphic Interpretation of Seismic Reflection Patterns in Depositional Sequences. In: Payton CE (Ed), Seismic Stratigraphy applications to hydrocarbon exploration. American Association of Petroleum Geologists, Tulsa, Memoir 26: 117-134.

NedeCO-ARConsult. 1983. Estudio de dragado del canal de acceso al Puerto de Bahía Blanca. Informe Geotécnico. Dirección Nacional de Construcciones Portuarias y Vías Navegables, Argentina, 105 p 
NORDFJORD S, GOFF JA, AUSTIN JR JA AND SOMMERFIELD CK. 2005. Seismic geomorphology of buried channel systems on the New Jersey outer shelf: assessing past environmental conditions. Mar Geol 214: 339-364.

PARKER G AND M PATERLINI. 1990. Apantallamientos acústicos en sedimentos gasíferos del río de la Plata. AGA Rev 45(1-2): 17-28.

QuARESMA VS, DiAs GTM AND BAPTISTA Neto JA. 2001. Caracterização da ocorrência de padrões de sonar de varredura lateral e sísmica de alta freqüência $(3,5$ e 7,0 $\mathrm{kHz}$ ) na porção sul da bahía de Guanabara-RJ. Rev Bras Geofís 18(2): 201-214.

Rabassa J, Coronato AM AND SAlemme M. 2005. Chronology of the Late Cenozoic Patagonian glaciations and their correlation with biostratigraphic units of the Pampean region (Argentina). J S Am Earth Sci 20: 81-103.

REYNOLDS JM. 1997. An Introduction to Applied and Environmental Geophysics. J Wiley \& Sons Ltd., Chichester, $778 \mathrm{p}$.

RigGS SR, CORK LL, WeHMILLER JF AND ZINDER SW. 1992. Depositional Patterns Resulting from High-frequency Quaternary Sea-level Fluctuations in Northeastern North Carolina. Quaternary Coasts of the United States: Marine and Lacustrine Systems, Society for Sedimentary Geology Special Publication 48: 141-153.
SpagnUOLO JO. 2005. Evolución geológica de la región costera-marina de Punta Alta, provincia de Buenos Aires. Tesis Doctoral Departamento de Geología, Universidad Nacional del Sur, inédito, Bahía Blanca, 269 p.

SpalletTi LA AND ISLA F. 2003. Características y evolución del delta del río Colorado ("Colú-Leuvú"), provincia de Buenos Aires, República Argentina. AAS Revista 10(1): 23-37.

Weschenfelder J, Corrêa IC, Aliotta S, Pereira C and VASCONCELLOS V. 2006. Shallow gas accumulations in the sediments of the Patos Lagoon area, southern Brazil. An Acad Bras Cienc 78: 607-614.

WeSCHENFELDER J, CORRÊA IC, TOLdo JR E AND BAITELli R 2008. Paleocanais como indicativo de eventos regressivos quaternários do nível do mar no sul do Brasil. Rev Bras Geofís 26(3): 367-375.

ZÁrate M, Schultz PH, Blasi A, HeIl C, King J AND Hames W. 2007. Geology and geochronology of type Chasicoan (late Miocene) mammal-bearing deposits of Buenos Aires (Argentina). J S Am Earth Sci 23: 81-90. 